\title{
Determinants of Property Insurance Demand in Slovak Republic: Challenges and Obstacles
}

\author{
Tomáš Ondruška ${ }^{1}$, Zuzana Brokešová ${ }^{2}$, Erika Pastoráková ${ }^{3}$ \\ University of Economics in Bratislava \\ Faculty of National Economy, Department of Insurance \\ Dolnozemská cesta 1, 85235 Bratislava, Slovak Republic \\ ${ }^{1} \mathrm{E}$-mail: tomas.ondruska@euba.sk \\ ${ }^{2}$ E-mail: zuzana.brokesova@euba.sk \\ ${ }^{3} \mathrm{E}$-mail: erika.pastorakova@euba.sk
}

\begin{abstract}
In the Slovak Republic, non-life insurance consumption is significantly lower compared to Western European countries. The paper tests various personal, demographic and economic factors and their impact on the individual property insurance demand in the Slovak Republic. Using survey data, we identified the following as statistically significant determinants of property insurance demand: gender, age, marital status, propensity to save, level of income, being a head of household. Our results can help insurers to better understand their potential consumers and to improve their acquisition and segmentation techniques. Our findings are important, especially, in times after launching a new tax on non-life insurance premiums, as individuals in Slovakia are very sensitive to the premium and often fail to buy adequate coverage in property insurance.
\end{abstract}

Keywords: consumer, insurance market, insurance consumption, determinants, property insurance

JEL code: G22

\section{Introduction}

Insurance plays an important role in the modern world and its importance is increasing due to emerging risks and frequent natural disasters. However, a general understanding of the insurance demand is limited contrary to individual's common sense. Insurance demand research largely focuses on life insurance; however, given the increasing volume of assets owned by individuals or households and the emerging risks that threaten these assets, it is necessary to study the demand for non-life insurance as well.

There are very few empirical works on individual non-life insurance demand. ${ }^{1}$ As a result, most existing studies only use macro data. The motivation of this paper is to contribute to the understanding of consumer behavior in the purchase of property insurance from the microeconomic perspective because individuals are

1 The reason for this may be the demand side represented not only by households and individuals but also companies as well as the obligation to buy some non-life insurance products. 
key representatives who make the final decision about the insurance purchase. The main aim of the paper is to identify key determinants associated with the property insurance consumption, which could help insurers to better understand their potential consumers and to emphasize the challenges of the Slovak non-life insurance market. In the paper, we do not focus on legal entities, but we limit our research to investigating the determinants of individuals' demand for non-life insurance. In our research, we only focus on the individuals' property insurance as a representative of non-life insurance market (with market share about $25 \%$ of whole non-life market (Axco, 2016)), abstaining from various liability and compulsory insurance policies.

The outlook of the performance of the non-life insurance industry in the Slovak Republic allows better understanding of its specifics. The performance of insurance industry is usually analyzed through three indicators: (1) volume of written premium, (2) insurance penetration ratio (gross written premiums to GDP), and (3) insurance density ratio (gross written premium per capita). The graphs of insurance density and penetration ratios (Figure 1 and Figure 2) indicate that they are not improving over time. The persistence of such trend causes that the assets of households in the Slovak Republic are less protected against the effects of random events.

Figure 1 Non-Life Insurance Penetration in Slovak Republic - GWP as a Percent of GDP

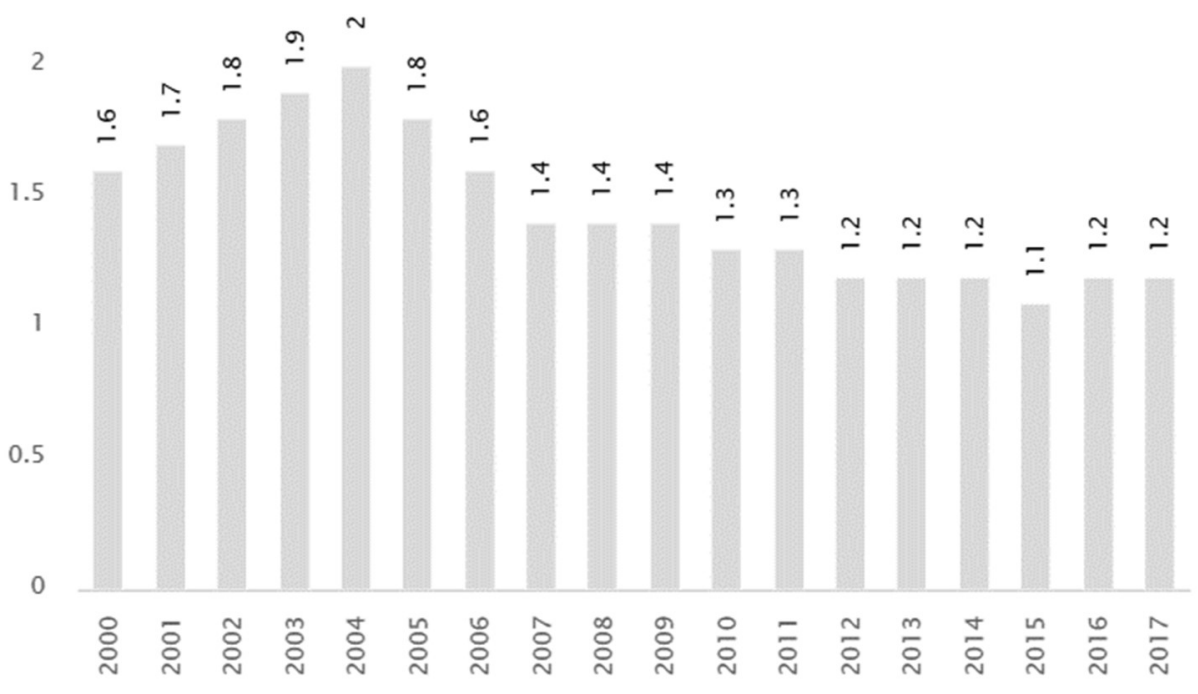

Source: AXCO \& Allianz Research.

Figures 1 and 2 indicate that insurance premium in non-life industry remains stable over time and the variance of the ratio is mainly driven by the GDP changes. It signalizes that the growing GDP has not brought about a substantial growth in nonlife insurance coverage demand. In Slovakia, the non-life insurance density index 
is associated with a significantly lower value of assets owned by households and commercial entities (which can be insured) as well as the fact that property insurance and willingness to cover various risks have low priority in the hierarchy of their needs. Unfavorable development points to the need to find answers to the question of how to stimulate demand for non-life insurance.

Figure 2 Non-Life Insurance Density in Slovak Republic - GWP per capita in EUR

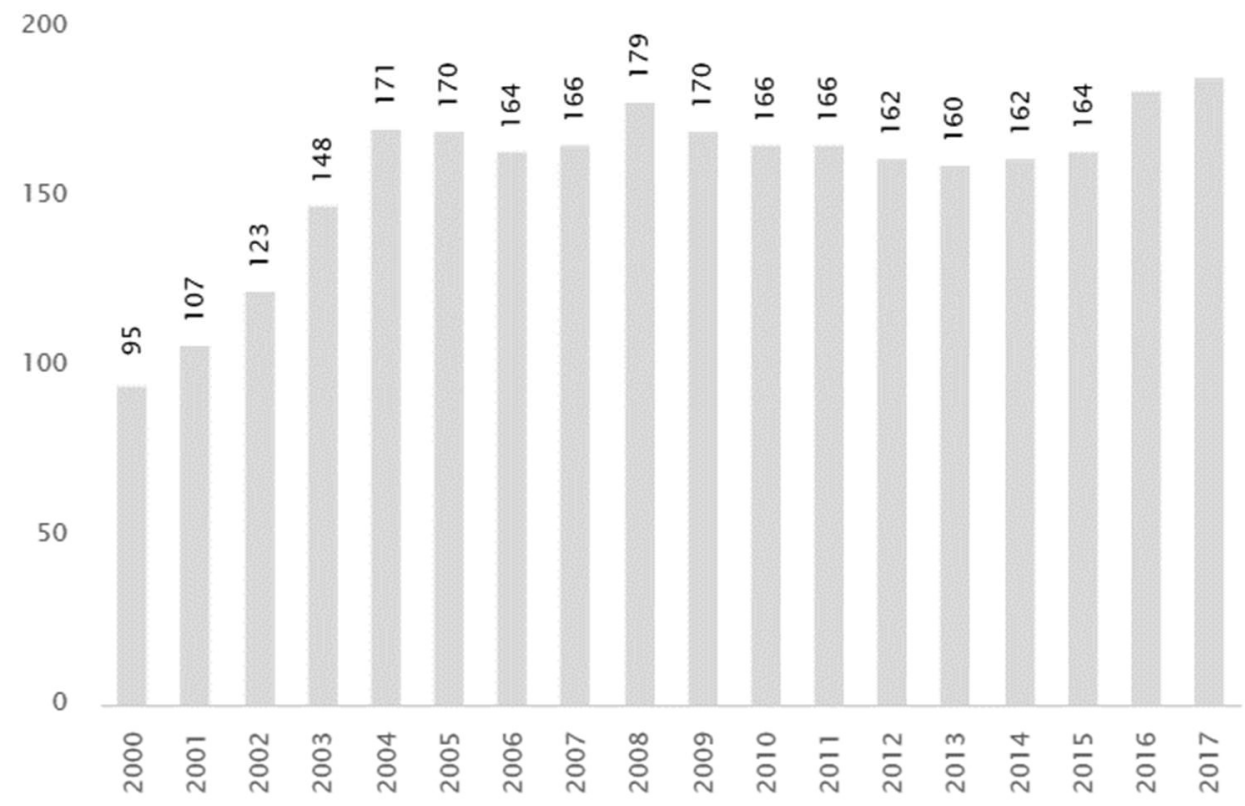

Source: AXCO \& Allianz Research.

Despite the unfavorable development of the non-life insurance industry, the most discussed issue in the non-life insurance sector is undoubtedly the taxation of insurance products. At present, taxation of non-life insurance products is based on three types of levies. The premium levy of $8 \%$ on compulsory motor third part liability products is paid to the Ministry of Internal Affairs of the Slovak Republic, to cover costs relating to fire brigades and traffic policing. The levy on supervised entities was amended in 2013 and subsequent years by virtue of the National Bank of Slovakia announcement $9 / 2012$, to $0.0131 \%$ per annum of the total amount of assets for insurers or reinsurers, subject to a minimum of EUR 1000 . Another act (starting from 2017) extended the levy at a rate of $8 \%$ of the premiums that insurance companies receive from compulsory car insurance (MTPL) to all sectors of non-life insurance. The Ministry of Finance of the Slovak Republic introduced an amendment to the act on insurance to boost revenues to the state budget as the sector had not been subject to taxes on such products before. However, the new act (starting from 2018) has introduced an indirect taxation system for the insurance, replacing the current special insurance $8 \%$ levy with the same rate on both old insurance contracts (with inception date before 2018) and new insurance 
contracts. In connection with this tax, it should be expected that it will be added to the final premium and ultimately will be borne mostly by the policyholders.

Tax as an economic instrument is not a modern phenomenon. Noel in his paper from 1909 stated that in times of wars, countries are compelled to resort to many forms of taxation of property and business which are considered oppressive (Noel, 1909). Nowadays, Slovak economy is experiencing a period of favorable economic development, so the timing of the introduction of the tax on insurance does not seem logical, also due to the persistent low penetration and density of insurance in the Slovak Republic compared to the advanced insurance markets. By introducing the tax, insurance will be less attractive to potential clients, so the effort to move closer to the advanced markets will be under threat.

\section{Literature Review}

Determinants that influence insurance purchases have been the focus of insurance research for many years. Studies define numerous variables that might be significant in explaining the demand for insurance (for a review see Zietz, 2003). Most of the researches analyze life insurance products solely because of the specific character of the non-life insurance products (some policies are mandatory in many countries, e.g. MTPL and in the case of non-life insurance legal entities play an important role). Many studies find results conflicting with previous research, and some of the contradictions are shown to be attributed to economic conditions of the country, demographics, or geographic factors.

There is no doubt that the extent of the research into demand for non-life insurance is low, especially when we take into account the number of published papers dealing with the life insurance consumption. Both, individuals (individual persons) and companies (legal entities) represent the demand side for non-life insurance. However, the decision to buy or not to buy insurance coverage remains with the individuals themselves (or a group of individuals). An individual has to decide for himself or herself, another person, or on behalf of a company.

Most of the previous papers dealing with the non-life insurance demand are based on the theoretical models in which the purchase of insurance is viewed as the exchange of a certain sum of money - premium - for a sum of money with uncertainty as a compensation.

Research into particular factors influencing demand for non-life insurance is significantly lower than the scope of papers focused on life insurance demand. The demand for non-life insurance was examined by several authors as Szpiro (1985), Beenstock et al. (1988), Outreville (1990), Browne et al. (2000), Esho et al. (2004), Hussels et al. (2005) and also Millo and Carmeci (2011), Khovidhunkit and Weiss (2005), Feyen et al. (2011) and Zhang and Zhu (2005). The list of studies published on the demand for non-life insurance is presented in Table 1. 
Table 1 Non-Life Insurance Demand Papers

\begin{tabular}{|c|c|c|c|}
\hline Year & Author(s) & Journal & Title \\
\hline 1985 & Szpiro & $\begin{array}{l}\text { The Journal of Risk and } \\
\text { Insurance }\end{array}$ & Optimal Insurance Coverage \\
\hline 1988 & $\begin{array}{l}\text { Beenstock, } \\
\text { Dickinson a } \\
\text { Khajuria }\end{array}$ & $\begin{array}{l}\text { The Journal of Risk and } \\
\text { Insurance }\end{array}$ & $\begin{array}{l}\text { The Relationship between } \\
\text { Property-Liability Insurance } \\
\text { Premiums and Income: An } \\
\text { International Analysis }\end{array}$ \\
\hline 1990 & Outreville & $\begin{array}{l}\text { The Journal of Risk and } \\
\text { Insurance }\end{array}$ & $\begin{array}{l}\text { The Economic Significance of } \\
\text { Insurance Markets in } \\
\text { Developing Countries }\end{array}$ \\
\hline 2000 & $\begin{array}{l}\text { Browne, Chung } \\
\text { a Frees }\end{array}$ & $\begin{array}{l}\text { The Journal of Risk and } \\
\text { Insurance }\end{array}$ & $\begin{array}{l}\text { International Property-Liability } \\
\text { Insurance Consumption }\end{array}$ \\
\hline 2004 & $\begin{array}{l}\text { Esho, } \\
\text { Kirievsky, Ward } \\
\text { a Zurbruegg }\end{array}$ & $\begin{array}{l}\text { The Journal of Risk and } \\
\text { Insurance }\end{array}$ & $\begin{array}{l}\text { Law and the Determinants of } \\
\text { Property-Casualty Insurance }\end{array}$ \\
\hline 2005 & $\begin{array}{l}\text { Hussels, Ward } \\
\text { a Zurbruegg }\end{array}$ & $\begin{array}{l}\text { Risk Management and } \\
\text { Insurance Review }\end{array}$ & $\begin{array}{l}\text { Stimulating the Demand for } \\
\text { Insurance }\end{array}$ \\
\hline 2011 & Millo a Carmeci & $\begin{array}{l}\text { Journal of Geographical } \\
\text { Systems }\end{array}$ & $\begin{array}{l}\text { Non-Life Insurance } \\
\text { Consumption in Italy: A Sub- } \\
\text { Regional Panel Data Analysis }\end{array}$ \\
\hline
\end{tabular}

Source: authors.

The table illustrates the significant number of studies performed for non-life insurance demand compared to life insurance.

We also use the results of research into life insurance demand determinants that can help us as a proxy for non-life insurance demand. Based on theoretical and empirical literature, we identify the most examined demographic and economic characteristics that could affect the demand for non-life insurance. These factors are age, gender, education, dependents, employment status, marital status, income, savings and religion.

An empirical study by Hammond et al. (1967) and a theoretical paper by Campbell (1980) found that one of the main purposes of life insurance is to protect dependents against financial hardship in the case of the breadwinner's premature death. From the non-life insurance perspective, it is also necessary to protect property as a possible means for inheritance. Campbell (1980) and Burnett and Palmer (1984) argued that the protection of dependents against financial hardships is the major force driving insurance consumption. Chui and Kwok (2008) found that with an increasing number of dependents, one needs to buy more insurance. Most of the previous studies provided empirical evidence that the consumption of insurance and the number of dependents are positively related (e.g. Hammond et al., 1967; Beenstock et al, 1989). 
Education lengthens the dependency period and a higher level of education may lead to a higher degree of risk aversion and more awareness of the necessity of insurance in general (Browne and Kim, 1993). The level of an individual's education may determine his/her ability to understand the benefits of risk management and savings (Beck and Webb, 2003). Education is related to greater awareness of the different types of risks and mitigation of their impact through insurance. Education is one of the few demographic determinants examined in studies of demand for non-life insurance. Outreville and Esho et al. (2004) confirmed its positive impact on demand in non-life insurance.

Age is found to be positively significant in majority of the studies, e.g. Showers and Shotick (1994), Truett and Truett (1990), and negatively significant in studies: Ferber and Lee (1980), Chen et al. (2001). Hammond et al. (1967) found age to be a significant factor affecting premium expenditures for insurance for low income and middle income groups. Showers and Shotick (1994) used the age of the respondents as a proxy for the "stage" of the family unit.

There are limited number of papers considering the gender as the determinant of insurance demand. Many studies confirm that women are more risk averse than men (Halek and Eisenhauer, 2001). Another recent study by Luciano et al. (2015) has found that women are less likely to be insured than men.

Browne and Kim (1993) suggested that religious people tend to purchase less insurance, because they perceive that buying life insurance shows a distrust of God's protection. Beck and Webb (2003) found that insurance consumption is significantly lower in Islamic countries than in other countries, whereas Outreville (1996) found that this relationship is weak. Feyen et al. (2011) proved that the presence of Islamic individuals in the population also has a negative impact on the development of non-life insurance market.

Employment status is expected to be positively related to life and non-life insurance demand as Miller (1985) reported that retirees have less insurance than active workers of the same age. Marital status influences the interest in insurance consumption positively (Halek and Eisenhauer, 2001; Baek and DeVaney, 2005). Although there is no paper directly focused on the determinant head of household, we included it in our analysis. Several studies (e.g. Hammond et al., 1967; Campbell, 1980) suggested that the head of household has its unique place, which makes it suitable to an increased interest in insurance.

Income is considered a key determinant of the insurance demand in majority of the studies. Higher income increases the standard of living as well as the wealth of individuals. As the income increases, insurance becomes more affordable. A positive impact of income on non-life insurance demand has been shown in majority of the studies, including Beenstock et al. (1988), Outreville (1990), Browne et al. (2000), Esho et al. (2004). The growth of individuals' income is followed by the growth of their assets, which are the subject of non-life insurance. Ultimately, 
growth in assets leads to the need for additional coverage through insurance, thereby increasing the demand for non-life insurance.

Savings of the individuals are undoubtedly connected with the income. However, the results regarding the impact of savings as a determinant of the non-life insurance demand are ambiguous in previous studies. While Rose and Mehr (1980) argued that the savings have a negative effect on the consumption of insurance, Headen and Lee (1974) found the opposite. These attitudes come from the perception of savings as a compensation of insurance or an additional source of funding.

We only mentioned the most important determinants of the demand for property insurance identified by the previous research. However, we can identify other microeconomic determinants of the individuals' demand for non-life insurance products as bequest motive, race, ownership of credit cards, house ownership, occupation and others.

\section{Methodology and Data}

We use survey data obtained by electronic (Google Form) and paper form to examine determinants of non-life insurance demand. The sample consists of respondents in an active phase of their lives from the Slovak Republic aged between 18 and 62 years. At the data collection stage, we received a total of 1044 respondents, out of whom we randomly selected a representative sample of 870 respondents, which corresponded to the distribution of the active population of the Slovak Republic by age and gender, according to the data from the Statistical Office of the Slovak Republic as shown in Tables 2 and 3.

Table 2 Gender Structure of Respondents

\begin{tabular}{cccccc}
\hline & & Frequency & Percent & Valid Percent & Cumulative Percent \\
\hline \hline \multirow{3}{*}{ Valid } & Man & 438 & 50.3 & 50.3 & 50.3 \\
\cline { 2 - 6 } & Woman & 432 & 49.7 & 49.7 & 100.0 \\
\cline { 2 - 6 } & Total & 870 & 100.0 & 100.0 & \\
\hline
\end{tabular}

Source: Authors' own calculations from survey.

Table 3 Age Structure of Respondents

\begin{tabular}{cccccc}
\hline & & Frequency & Percent & Valid Percent & Cumulative Percent \\
\hline \hline \multirow{3}{*}{ Valid } & $\mathbf{1 8 - 2 4}$ & 131 & 15.1 & 15.1 & 15.1 \\
\cline { 2 - 6 } & $\mathbf{2 5}-\mathbf{3 9}$ & 331 & 38.0 & 38.0 & 53.1 \\
\cline { 2 - 6 } & $\mathbf{4 0 - 6 2}$ & 408 & 46.9 & 46.9 & 100.0 \\
\cline { 2 - 6 } & Total & 870 & 100.0 & 100.0 & \\
\hline
\end{tabular}

Source: Authors' own calculations from survey. 
Due to a categorical character of our variables, we use logistic regression in SAS Enterprise Guide program to examine determinants of individual demand for nonlife property insurance. The dependent variable that we model is the ownership of individual property insurance, namely homeowners and householders insurance. Mathematically, a binary logistic model has a dependent variable with two possible values, such as insurance ownership or no insurance ownership, and these are represented by an indicator variable, where the two values are labeled " 1 " and " 0 ".

As explanatory variables, we chose gender (GEN), age (AGE), savings (SAV), income (INC), education (EDU), head of household (HEAD), employment status (EMPL), marital status (MAR_S), dependent children (DEP), and religion (REL). Definitions of explanatory variables are provided in Table 4.

Table 4 List of Explanatory Variables Used in Model

\begin{tabular}{|c|c|}
\hline Variable & Definition \\
\hline GENDER & Binary variable equaling one for woman. \\
\hline AGE & $\begin{array}{l}\text { Variable denoting subject's age period }(0=18-24 ; 1=25-39 ; 2=40- \\
62) .\end{array}$ \\
\hline $\begin{array}{l}\text { MARITAL } \\
\text { STATUS }\end{array}$ & $\begin{array}{l}\text { Binary variable equals one for those who are married or live with a } \\
\text { partner. }\end{array}$ \\
\hline INCOME & $\begin{array}{l}\text { Variable denoting subject's gross monthly income group }(0=\text { under } \\
330 \text { EUR; } 1=331-880 \text { EUR; } 2=881-1500 \text { EUR, } 3=\text { over } 1500 \text { EUR }) .\end{array}$ \\
\hline SAVINGS & Binary variable equaling one for those who make savings. \\
\hline EDUCATION & Binary variable equaling one for university graduates. \\
\hline $\begin{array}{l}\text { HEAD OF } \\
\text { HOUSEHOLD }\end{array}$ & Binary variable equaling one for those who are heads of households. \\
\hline $\begin{array}{l}\text { DEPENDENT } \\
\text { CHILDREN }\end{array}$ & Binary variable equaling one for those who have at least one child. \\
\hline $\begin{array}{l}\text { EMLOYMENT } \\
\text { STATUS }\end{array}$ & $\begin{array}{l}\text { Variable denoting subject's status on labor market }(0=\text { employed; } 1= \\
\text { entrepreneurs; } 2=\text { students, unemployed or pensioners }) .\end{array}$ \\
\hline RELIGION & Binary variable equaling one for those who are believers. \\
\hline
\end{tabular}

In the first step, we test the determinants and find the interdependencies between them to exclude multi-collinearity. The analysis of the determinants of the demand for insurance is conducted through logistic regression. We chose this type of regression because of the categorical nature of our variables. Due to the nature of the explained variables, logistic regression is a special type of generalized linear model. In the logistic model, the log-odds for the ownership of property insurance is a linear combination of several independent variables which can each be a binary variable (two classes, coded by an indicator variable) or a continuous variable (any real value). The corresponding probability of the property insurance ownership can 
vary between 0 (certainly the value "0") and 1 (certainly the value "1"). The function that converts log-odds to probability is the logistic function. The unit of measurement for the log-odds scale is called a logit, from logistic unit, hence the alternative names.

$$
\operatorname{logit}(p)=\log \left(\frac{\pi}{1-\pi}\right)=\beta_{0}+\beta_{1} X_{1}+\beta_{2} X_{2}+\ldots+\beta_{k} X_{k}
$$

where $\begin{aligned} & \beta_{0}, \beta_{1}, \ldots,- \text { regression coefficients, } \\ & \beta_{K}\end{aligned}$

$\Pi \quad-\quad$ the conditioned mean value of the dependent variable.

The moderate association rate is present between the determinants: MAR_S and DEP; MAR_S and AGE; INC and SOC_S. Due to the presence of a moderate association rate between MAR_S and DEP variables, we included another variable of their cross effect MAR_S* DEP. We also wanted to include other MAR_S * AGE and INC * SOC_S crossover variables, but the quality of the logistics model did not improve. For this reason, we did not include these interaction variables in the resulting model.

\section{Results and Discussion}

The non-life insurance demand model is statistically significant at the significance level 0.05. At this level of significance, several parameters are statistically significant: gender (GEN), age (AGE), marital status (MAR_S), savings (SAV), income (INC), head of household (HEAD). Results of our logistic model are shown below:

$$
\begin{array}{rl}
\operatorname{logit}(\hat{p})=0,02 & 95-0,4273 G E N-1,6102 A G E 1-0,8981 A G E 2+0,7767 M A R \_S \\
& -0,8340 S A V+0,3592 I N C 1+1,0067 I N C 2+1,5203 I N C 3 \\
& +0,0364 E D U-0,5475 H E A D+0,3733 E M P L \_1+0,4252 E M P L \_2 \\
& -0,4185 D E P+0,5281 M A R \_S * D E P+0,1355 R E L 1+0,0905 R E L 2 .
\end{array}
$$

Complete results from logistic regression are shown in Table 5.

The determinant gender (GEN) is statistically significant in our model. The chance of ownership of non-life insurance product by a man is 0.65 times the odds compared to a woman. Women are, therefore, more interested in non-life insurance. Their higher rate of risk aversion thus manifests itself not only in life insurance but also in the protection of owned property. The results of Gandolfi and Miners (1996) showed an increased interest of women in life insurance, and we can extend these findings to non-life industry - property insurance.

As regards variable age (AGE), we have confirmed a statistically significant impact in all its subcategories. The chance that an individual between the ages of 18 and 24 will have a non-life insurance contract is 0.20 times the chance of an individual who is between 40 and 61 years old. Although this chance has doubled in the 2539 age category, the odds ratio is 0.41 times for those aged 40 to 61 . The continued 
growth of interest in non-life insurance with higher age is obvious. The cause can be found primarily in the gradual obtaining of property during an individual's lifetime. The increasing amount of property also generates a higher need for insurance cover.

Table 5 Model Parameters and Significance Tests

\begin{tabular}{|c|c|c|c|c|c|c|}
\hline \multicolumn{7}{|c|}{ Analysis of Maximum Likelihood Estimates } \\
\hline Parameter & & DF & Estimate & $\begin{array}{l}\text { Standard } \\
\text { Error }\end{array}$ & $\begin{array}{l}\text { Wald } \\
\text { Chi- } \\
\text { Square }\end{array}$ & Pr $>$ ChiSq \\
\hline Intercept & & 1 & 0.0295 & 0.5112 & 0.0033 & 0.9539 \\
\hline GEN & Man & 1 & -0.4273 & 0.1739 & 6.0347 & 0.0140 \\
\hline AGE1 & $18-24$ & 1 & -1.6102 & 0.3605 & 19.9516 & $<0.0001$ \\
\hline AGE2 & $25-39$ & 1 & -0.8981 & 0.1945 & 21.3098 & $<0.0001$ \\
\hline MAR_S & Married/Living in couple & 1 & 0.7767 & 0.3039 & 6.5326 & 0.0106 \\
\hline SAV & No & 1 & -0.8340 & 0.2182 & 14.6136 & 0.0001 \\
\hline INC1 & $331-880 €$ & 1 & 0.3592 & 0.3535 & 1.0323 & 0.3096 \\
\hline INC2 & $881-1500 €$ & 1 & 1.0067 & 0.3920 & 6.5954 & 0.0102 \\
\hline INC3 & over $1500 €$ & 1 & 1.5203 & 0.4682 & 10.5459 & 0.0012 \\
\hline EDU & Primary / Secondary & 1 & 0.0364 & 0.1822 & 0.0399 & 0.8416 \\
\hline HEAD & No & 1 & -0.5475 & 0.1780 & 9.4561 & 0.0021 \\
\hline EMPL_1 & Employed & 1 & 0.3733 & 0.2876 & 1.6844 & 0.1943 \\
\hline EMPL_2 & Self-employed & 1 & 0.4252 & 0.3539 & 1.4437 & 0.2295 \\
\hline DEP & No & 1 & -0.4185 & 0.3137 & 1.7801 & 0.1821 \\
\hline MAR_S*DEP & Married/Living in couple No & 1 & 0.5281 & 0.3935 & 1.8012 & 0.1796 \\
\hline REL1 & Nonbeliever & 1 & 0.1355 & 0.2825 & 0.2299 & 0.6316 \\
\hline REL2 & Believer & 1 & 0.0905 & 0.2628 & 0.1186 & 0.7306 \\
\hline
\end{tabular}

Note: Model parameters: -2 Log Likelihood 893,544; AIC 927,544; SC 1008,608. Source: Authors.

Marital status (MAR_S) is also a statistically significant determinant of demand for non-life insurance. The chance that an individual will buy the non-life insurance policy as a change of his status from single to married increases 2.17 times. The commitments are related, among other things, to the need for an individual's own housing, or an acquisition of movable and immovable property, which creates prerequisites for widening coverage of risks in non-life insurance. Individuals are aware of the need to protect common values, which they can properly address through insurance. 
We can confirm a positive and significant impact of savings (SAV) on non-life insurance interest. If an individual does not save money, his or her chance of ownership of the non-life insurance product is 0.43 times that of the person making savings. The fact that an individual creates savings is also related to one of the motives for handling free means for the growth of property. This also increases the need for insurance cover. Savings are related not only to better availability of property insurance but also to their investment in the purchase of additional assets.

Income (INC) is one of the few determinants investigated in the research of demand for property insurance to a higher extent. Our findings are similar to studies by Beenstock et al. (1988), Browne et al. (2000) and Esho et al. (2004). Growth of income is also linked to the growth of assets. Income can be also used for consumption of items that are not necessary in the lives of individuals (including insurance).

Determinant head of household (HEAD) is statistically significant in our model. The person who is the head of a household has a higher chance of the ownership of property insurance. These individuals often have different types of non-life insurance policies, although other members of the household can also take part in the decision process to buy them, and act as the main policyholder.

In our model, we do not support the assumption on the positive impact of education (EDU) on the demand for property insurance confirmed by Outreville (1990), as well as Esho et al. (2004). Our model brings similar non-significant results for other factors as employment status (EMPL), dependent children (DEP) and religion (REL).

\section{Conclusions}

Research into the factors influencing the demand for non-life insurance is in large contrast to research published on life insurance. While the interest of individual consumers in life insurance has been investigated in many studies, only marginal attention has been devoted to non-life insurance. The reason is the nature of nonlife insurance, the obligation to buy some types of non-life insurance, but also the fact that the demand for non-life insurance is also represented by legal entities. By using logistic regression and survey data, we have identified determinants of individual interest in non-life property insurance in the Slovak Republic. The paper contributes to the understanding of consumer behavior in the purchase of property insurance from the microeconomic perspective. As there are very few existing empirical studies on non-life insurance demand due to the lack of household-level data of insurance, our contribution enriches the existing literature and we assume our findings can motivate more research in this field. We identified the following as statistically significant determinants of property insurance demand: gender (GEN), age (AGE), marital status (MAR_S), savings (SAV), income (INC), head of household (HEAD).

We focused on individual demand for property insurance, as we assume that this segment will be most affected by tax introduction. Our previous research has 
already highlighted the fact that individuals are very sensitive to the price of insurance products (Pastoráková et al., 2013). The results of the current research point to the fact that higher-income individuals mainly represent the demand for property insurance. For low-income individuals, property insurance will become even less available after the introduction of the tax. However, these consumers are the most vulnerable to unforeseen events. From the gender perspective, as women are more interested in property insurance, the introduction of the tax may have an impact mainly on this group of policyholders. This is mainly due to the lower wage that women receive at the same position as compared to men. Introduction of the new tax under other unchanged conditions will also reduce the disposable income of individuals. If policyholders do not want to pay higher premiums, they will need to reduce the coverage (sum insured) or the extent of risks covered. This may ultimately negatively affect the reputation of the insurance sector.

Our results can help in addressing the marketing of insurance companies, especially by focusing on the segments of potential clients with insufficient insurance coverage or without any policy. On the other hand, our results may also help identify the vulnerable groups of policyholders, which can be affected by the introduction of the new tax on non-life insurance products because of higher premium. The results can also be beneficial to insurance association to get other arguments against taxation of non-life insurance products.

Additionally, there are many challenges for non-life insurance companies ahead. Firstly, it is necessary to improve the industry development through active sales of insurance products, which are in line with GDP growth. Numerous long-term property insurance contracts on the market have insufficient coverage. Terminating of these contracts would create potential for market growth. The role of insurers is also to contribute to citizens' awareness of property protection issues through insurance and not to rely on government aid in the event of any disaster.

\section{Acknowledgments}

This paper is part of research project No. I-18-106-00 entitled 'Analysis of Methods and Approaches Applicable to the Research of Demand-side Determinants in the Context of the innovations that form the insurance market' provided by the University of Economics in Bratislava and research project No. 1/0827/18 entitled 'Experimental investigation of factors influencing group decision-making' provided by the Ministry of Education, Science, Research and Sport of the Slovak Republic.

\section{References}

Allianz Research. (2018). Allianz Global Insurance Map.

AXCO. (2016). Insurance Market Report. SLOVAKIA: NON-LIFE (P\&C)

Baek, E., Devaney, S.A. (2005) Human Capital, Bequest Motives, Risk, And The Purchase of Life Insurance. Journal of Personal Finance, 4(2), pp. 62-84. 
Beck, T. and Webb, I. (2003). Economic, Demographic, And Institutional Determinants of Life Insurance Consumption Across Countries. World Bank Economic Review, 17(1), pp. 51-88.

Beenstock, M., Dickinson, G. and Khajuria, S. (1988). The Relationship between Property-Liability Insurance Premiums and Income: An International Analysis. The Journal of Risk and Insurance, 55(2), pp. 259-272.

Browne, M. J. and Kim, K. (1993). An International Analysis of Life Insurance Demand. Journal of Risk and Insurance, 60(4), pp. 616-634.

Browne, M.J., Chung, J. and Frees, E.W. (2000). International Property-Liability Insurance Consumption. The Journal of Risk and Insurance, 67(1), pp. 73-90.

Burnett, J.J. and Palmer, B.A. (1984). Examining Life Insurance Ownership Through Demographic and Psychographic Characteristics. The Journal of Risk and Insurance, 51(3), pp. 453-467.

Campbell, R.A. (1980). The Demand for Life Insurance: An Application of the Economics of Uncertainty. The Journal of Finance, 35(5), pp. 1155-1172.

Esho, N., Kirievsky, A., Ward, D. and Zurbruegg, R. (2004) Law and the Determinants of Property-Casualty Insurance. The Journal of Risk and Insurance, 71(2), pp. 265-283.

Ferber, R. and Lee, L.C. (1980). Acquisition and Accumulation of Life Insurance in Early Married Life. The Journal of Risk and Insurance, 47(4), pp. 132-152.

Feyen, E., Lester, R. and Rocha, R. (2011). What Drives the Development of the Insurance Sector? An Empirical Analysis Based on a Panel of Developed and Developing Countries. Policy Research Working Paper Series No. 5572, The World Bank, 2013. 45 pp.

Gandolfi, A.S. and Miners, L. (1996). Gender-Based Differences in Life Insurance Ownership. The Journal of Risk and Insurance, 63(4), pp. 683-693.

Halek, M. and Eisenhauer, J.G. (2001). Demography of Risk Aversion. The Journal of Risk and Insurance, 68(1), pp. 1-24.

Hammond, J.D., Houston, D.B. and Melander, E.R. (1967). Determinants of Household Life Insurance Premium Expenditures: An Empirical Investigation. The Journal of Risk and Insurance, 34(3), pp. 397-408.

Headen, R.S. and Lee, J.F. (1974). Life Insurance Demand and Household Portfolio Behavior. The Journal of Risk and Insurance, 41(4), pp. 685-698.

Hussels, S. and Ward, D., Zurbruegg, R. (2005). Stimulating The Demand for Insurance. Risk Management and Insurance Review, 8(2), pp. 257-278.

Chen, R., Wong, K.A. and Lee, H.C. (2001). Age, Period, And Cohort Effects On Life Insurance Purchases in the U.S. The Journal of Risk and Insurance, 68(2), pp. 303327.

Chui, A.C.W. and Kwok, C.C.Y. (2008). National Culture and Life Insurance Consumption. Journal of International Business Studies, 39(1), pp. 88-101. 
Khovidhunkit, P. and Weiss, M.A. (2005). Demand for Automobile Insurance in the United States. Working Paper, Temple University Philadelphia, 2005. 11 p. <http://iceb.nccu.edu.tw/proceedings/APDSI/2002/papers/paper119.pdf>.

Luciano, E., Outreville, F. and Rossi, M. (2015). Life Insurance Demand Evidence from Italian Households: A Microeconomic View and Gender Issues. Netspar 2015.

Miller, M.A. (1985). Age-Related Reductions in Workers's Life Insurance. Monthly Labor Review, pp. 29-34.

Millo, G. and Carmeci, G. (2011). Non-Life Insurance Consumption in Italy: A SubRegional Panel Data Analysis. Journal of Geographical Systems, 13(3), pp. 273298.

Noel, J.W. (1909). Taxation of Insurance. State and Local Taxation: International Conference under the Auspices of the International Tax Association: Addresses and Proceedings, 3, pp. 111-128.

Outreville, J.F. (1990). The Economic Significance of Insurance Markets in Developing Countries. The Journal of Risk and Insurance, 57(3), pp. 487-498.

Outreville, J.F. (1996). Life Insurance Markets In Developing Countries. The Journal of Risk and Insurance, 63(2), pp. 263-278.

Pastoráková, E., Janíková, T., Brokešová, Z. and Ondruška, T. (2013). Rodové rozdiely vo finančnom rozhodovaní $v$ oblasti životného poistenia na Slovensku. Ekonomický časopis, 61(1), pp. 82-100.

Rose, T. and Mehr, R.I. (1980). Flexible Income Programming. The Journal of Risk and Insurance, 47(1), pp. 44-60.

Showers, V.E. and Shotick, J.A. (1994). The Effects of Household Characteristics On Demand for Insurance: A Tobit Analysis. The Journal of Risk and Insurance, 61(3), pp. 492-502.

Szpiro, G.G. (1985). Optimal Insurance Coverage. The Journal of Risk and Insurance, 52(4), pp. 704-710.

Zhang, C. and Zhu, N. (2005). Determinants of the Development of Insurance in China Under the Globalization. Working Paper, 2005, 27 p. <http://www.cerdi.org/uploads/sfCmsContent/html/200/Zhang_31.pdf>.

Zietz, E.N. (2003). An Examination of the Demand for Life Insurance. Risk Management and Insurance Review, 6(2), pp. 159-191. 